\title{
Physicochemical Differentiation of the Muskau Arch Pit Lakes in the Light of Long-Term Changes
}

\author{
Małgorzata Oszkinis-Golon ${ }^{1}$, Marcin Frankowski ${ }^{2}$, Leszek Jerzak $^{1}(\mathbb{C})$ and Andrzej Pukacz ${ }^{3, *}$ \\ 1 Institute of Biological Sciences, University of ZielonaGóra, Prof. Z. Szafrana1, 65-516 ZielonaGóra, Poland; \\ gosiaoszkinis@wp.pl (M.O.-G.); 1.jerzak@wnb.uz.zgora.pl (L.J.) \\ 2 Faculty of Chemistry, Adam Mickiewicz University, Uniwersytetu Poznańskiego 8, 61-614 Poznań, Poland; \\ marcin.frankowski@amu.edu.pl \\ 3 Collegium Polonicum, Adam Mickiewicz University, Kościuszki 1, 69-100 Słubice, Poland \\ * Correspondence: pukacz@europa-uni.de
}

Received: 13 May 2020; Accepted: 20 August 2020; Published: 24 August 2020

check for updates

\begin{abstract}
Thirteen pit lakes of the Muskau Arch (Western Poland) were studied in the summer season of 2016. The lakes display great geomorphological and hydrochemical diversity. The aim of the study was to characterize temporal changes in the physicochemical conditions of the pit lakes over the last 30 years (1986-2016) and to determine the main factors influencing their evolution. All the lakes were characterized in terms of the same set of physicochemical parameters measured and used for comparative analysis with literature data from the years 1986 and 1992. The results showed significant temporal differentiation in terms of morphometric features and most of the physicochemical characteristics. $\mathrm{pH}, \mathrm{EC}, \mathrm{Ca}^{2+}, \mathrm{Mg}^{2+}$ and total Fe were among the most significantly differentiating parameters. A similar pattern of changes was found for most of the lakes, suggesting natural fluctuations. Despite the differences in values of thermal and oxygen profiles, there were also similarities in lake stratification. Additionally, meromictic conditions were found in 4 lakes. In some of the lakes a negative effect of neutralization and fertilization of the water was observed. Our results showed that the Muskau Arch lakes are subject to dynamic hydrogeological and hydrochemical changes. In addition to natural changes, human-caused transformations were among the key factors responsible for the differentiation of the physicochemical conditions.
\end{abstract}

Keywords: pit lakes; Muskau Arch; water chemistry; temporal changes

\section{Introduction}

Apart from natural water ecosystems, pit lakes have been a permanent element of the landscape for many centuries. Depending on the kind of ore extracted there in the past, pit lakes may be formed in former brown coal, clay, sand and gravel mines, building stone quarries and peat bogs [1]. The kind of extracted material and the materials later present in the lake basin significantly affect the physicochemical parameters of the water, which is reflected, i.e., in the different colors of water [2]. An important element affecting the morphometric structure-and thus, later habitat diversity of the lakes - is their genesis (the way of extraction). Depending on whether the lakes are formed in the place of open pits (open pit lakes) or underground workings (sink hole lakes), the processes occurring there differ in dynamics and scope [3,4].

Lakes formed in places of brown coal mining are predominant in Poland [5]. They are very different in terms of water chemistry, which is mainly due to the very low $\mathrm{pH}$ (often below 3 ) as well as high mineralization [6,7]. 
The main source of water acidification in mine lakes is oxidation of iron sulfide containing minerals (pyrite and marcasite) in lignite and shale residues left around the lake [8]. The following equation describes pyrite oxidation and the production of acidity:

$$
\mathrm{FeS}_{2}+3.75 \mathrm{O}_{2}+3.5 \mathrm{H}_{2} \mathrm{O} \rightarrow \mathrm{Fe}(\mathrm{OH})_{3} \downarrow+2 \mathrm{SO}_{4}{ }^{2-}+4 \mathrm{H}^{+}
$$

The products of this reaction are: iron hydroxide (responsible for the color of water), sulfate ions, and hydrogen ions (responsible for the acidification of the water). The core product of this process is a strong sulfuric acid solution. This acid solution leaches heavy metals and aluminum from rocks and soils producing a highly toxic mixture [8].

As a result, conditions in many such lakes hamper the development of living organisms, which affects the speed of evolutionary transformations occurring there [9].

Water chemistry and the morphometric structure of workings in which the lakes are formed also have a big influence on the frequency and scope of water mixing. As in the case of natural lakes, water in deep pit lakes is vertically stratified [10], and thus, their biocenoses are stratified as well. Therefore, it is an important element affecting the functioning of the whole ecosystem.

While in natural lakes, stratification results mostly from variability in temperature, according to the seasons [11], in artificial mine pit lakes this is chemical stratification caused by considerable differences in water density, mainly resulting from its mineralization [12]. The inflow of water with high concentrations of various salts (in the case of brown coal mines, mostly pyrite) is the consequence of disturbing (cutting through) the aquifer when extracting the ore and washing out from the overburden by rainwater [13]. In addition, high salinity groundwaters accumulating in the deepest parts of the lake have the tendency to stratify all of the time [14]. Apart from higher mineralization of waters, pit lakes also differ from natural lakes in that they are usually deep in relation to their surface area. As a result, pit lakes can evolve to a state of permanent stratification known as meromixis [15]. In this case, only surface water layers (mixolimnion) are mixed, and the deepest layers (monimolimnion) are permanently isolated from the surface waters by the chemocline [12]. The monimolimnion by itself can nonetheless mix by internal processes albeit very slowly, e.g., groundwater inflow, molecular diffusion etc.; but there is no or very limited exchange between mixolomnion and monimolimnion. There is a clear chemocline between them, where the concentrations of many elements increase rapidly [11]. This phenomenon is persistent because of huge differences in water density. The morphometric structure also plays an important part in stratification. However, in shallower or less strongly stratified lakes external forces (e.g., wind, heat exchange, inflows) can lead to complete mixing, and thus meromixis is not a characteristic of pit lakes.

The diversity of water chemistry of pit lakes is reflected in the water color of those lakes. For this reason, they are often called colorful lakes and currently constitute an integral and unique element of the landscape [16]. Processes influencing the temporal variability of pit lakes are still poorly known due to their complexity (including, i.e., as mentioned earlier, low $\mathrm{pH}$, chemical stratification, or very slow secondary succession) and individual character related to i.e., the variability of the subsoil or water inflow [17]. Natural disturbances of stratification caused by wind and seasonal mixing, which may change water chemistry, usually require ample time and potentially permanent stratification can build up again but this needs specific conditions [10]. A much more common situation is the disturbance of pit lakes' stratification caused by water neutralization. The neutralization can be twofold: natural or anthropogenic. Natural neutralization in pit lakes occurs i.e., by means of inflow of rainwater and groundwaters (dilution of acidic waters). Anthropogenic neutralization is purposeful activity implemented in many countries as a method of lake recultivation [9]. In the case of pit lakes, calcium hydroxide is the most commonly used agent to reduce acidity [18]. It leads to a long term effect depending on the chemistry of lakes, especially the ability of iron and aluminum rich waters to immobilize the carbonate molecules and the hydrological regime of the lakes [9]. Upon exceeding $\mathrm{pH} 4.5$, the neutralization process is very quick and hard to reverse [8]. Such actions often result in 
degradation (over fertilization) of lakes, which leads to increased water trophy. Thus, as a result of human activities, the unique character of pit lakes is changing.

The Muskau Arch is one of the biggest clusters of pit lakes in Europe. Pit lakes located in this area were formed at the turn of the 20th century [19]. Most of them were the result of brown coal extraction, often accompanied by the extraction of clay and sand [20]. Depending on the extracted ore, the lakes have different chemical composition [1]. The hydrochemical and hydrobiological properties of lakes located within the Muskau Arch are still not well known. Most of the available literature data from this area concern either single objects [21,22] or, if more lakes were analysed, there are only regional-wide reports $[23,24]$. It mainly results from the fact that they are located in poorly accessible places (with hills and forests), and thus for years they were known only to the local people. Therefore, many of them have never been transformed by human activity, maintaining their original character. However, although the area is under protection as the Muskau Arch Landscape Park since 2001 and its most valuable area is a part of the first in Poland Geopark (Muskau Arch Geopark), there is still no consistent monitoring and management plan for the lakes. As a result, degradation processes and accelerated decline of lakes occur in many places. Liming and fertilization (e.g., with domestic wastewater) in order to stock the lakes with fish (mostly with carp), despite being legally forbidden, are quite common in these lakes. The results from other regions shows], these are one of the main processes that lead to irreversible negative changes in such ecosystems $[25,26]$. In order to protect the unique character and diversity of these lakes, it seems necessary to recognize the trends of water chemistry changes and their causes.

The aim of the study was to determine temporal changes in the physicochemical conditions of the Muskau Arch pit lakes within the years 1986-2016 and the main factors influencing their evolution. We hypothesized that the lakes undergo temporal variability of physical-chemical water conditions, both through natural evolution and dynamic hydrology induced by external factors.

\section{Study Area and Methods}

In the summer season of 2016, 13 pit lakes of the Muskau Arch (Western Poland) were selected for comparative analysis with literature data from the years 1986 and 1992 (Figure 1). The lakes are of postmining origin (mostly brown coal mining) and belong to the so-called anthropogenic lake district [27].

Regarding the genesis, three groups of lakes were identified: sink hole, open-cut and sink hole/open-cut lakes. Sink hole lakes were formed as a result of underground brown coal extraction. Open-cut lakes were formed in the places of open pits, mostly after the extraction of clay. Sink hole/open-cut lakes were formed as a result of underground brown coal extraction and open-cut clay extraction [27]. Several types of lakes can be distinguished as regards their genesis: lakes created in former brown coal, clay, sand and gravel mines [1]. The genesis and age of the lakes were determined on the basis of historical data analysis [28] and literature quoted therein as well as geological maps and unpublished sources of the Polish Geological Institute in Wrocław (Koźma 2018, unpublished data).

Before the survey, a Lowrance Mark $5 \times$ Pro sonic depth finder was used in each lake to determine its maximum depth. To avoid potential bottom anomalies the depth measurement was performed in a traverse transects. The maximum depth and surface results were compared with the data by [24]. The surface area of each lake was determined using maps and satellite images as well as Geoportal tools. In the case of the 1986 data, the measurement was used by a transect method with the use of portable steel roller water level meter with a weighter, which at that time was a standard method.

The depth of the lakes varied from 1.8 to $22.4 \mathrm{~m}$, and the surface area, from 0.11 to 18.45 ha (Table 1 ). The largest and deepest lake was lake No. 12, located near the village of Łeknica. The smallest one is lake No. 2, and the shallowest, lake No. 1, both located near Tuplice. The comparison with data by Jędrczak [24] showed that all lakes in 2016 had a smaller surface area than in 1986. The opposite is true for the maximum depth, which, except for lake No. 12, has increased compared to 1986. The greatest increase of the depth was in lake No. $26(6 \mathrm{~m})$ and in lakes No. 11 and $25(5 \mathrm{~m})$. 


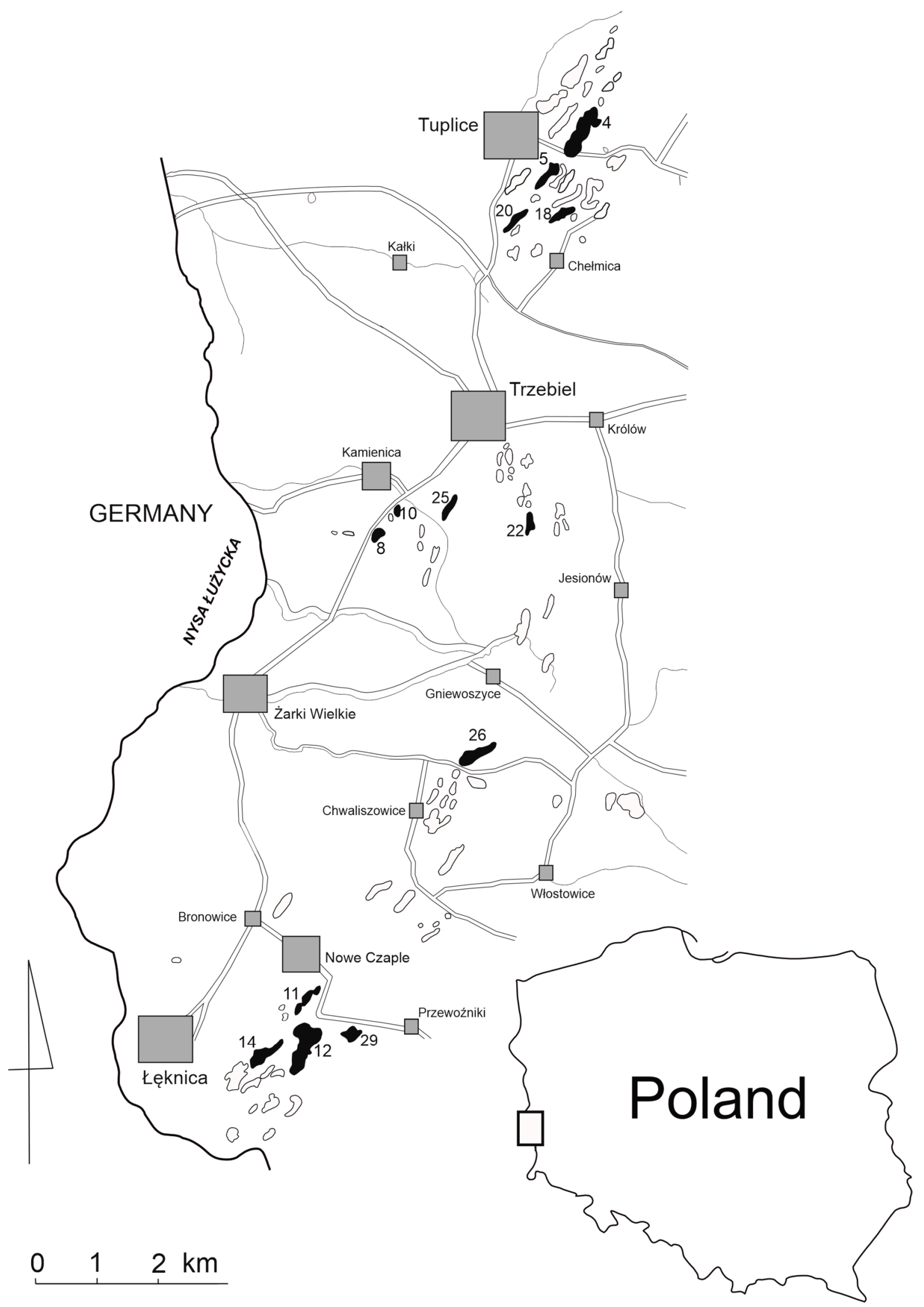

Figure 1. Location and spatial distribution of the investigated lakes (marked in black and numbered). 
Table 1. Basic characteristics of the investigated pit lakes. Abbreviations: S—sink hole, $\mathrm{O}-$ open-cut, $\mathrm{S}-\mathrm{O}-\operatorname{sink}$ hole-open-cut.

\begin{tabular}{|c|c|c|c|c|c|c|c|}
\hline $\begin{array}{l}\text { Lake No. by } \\
\text { Pukacz et al., } \\
\text { 2017. [27] }\end{array}$ & $\begin{array}{c}\text { Lake No. by } \\
\text { Jędrczak } \\
\text { 1992. [24] }\end{array}$ & Genesis & $\begin{array}{c}\text { Age } \\
\text { (Years) }\end{array}$ & $\begin{array}{c}\text { Area by } \\
\text { Pukacz et al., } \\
2017 \text { (ha) [27] }\end{array}$ & $\begin{array}{c}\text { Area by } \\
\text { Jędrczak } \\
1992 \text { (ha) [24] }\end{array}$ & $\begin{array}{c}\text { Max Depth by } \\
\text { Pukacz et al., } \\
2017(\mathrm{~m})[27]\end{array}$ & $\begin{array}{l}\text { Max Depth } \\
\text { by Jędrczak } \\
1992(\mathrm{~m})[24]\end{array}$ \\
\hline 4 & 8 & $S$ & 145 & 11.79 & 15.0 & 2.8 & 1.5 \\
\hline 8 & 31 & $S$ & 113 & 1.89 & 1.9 & 10.2 & 7.5 \\
\hline 10 & 28 & S & 90 & 1.27 & 1.75 & 4.5 & 4.0 \\
\hline 14 & 55 & S-O & 42 & 6.09 & 6.25 & 9.4 & 9.0 \\
\hline 18 & 15 & $\mathrm{O}$ & 79 & 2.16 & 3.12 & 7.4 & 5.5 \\
\hline 20 & 16 & $\mathrm{~S}-\mathrm{O}$ & 117 & 2.31 & 2.66 & 4.4 & 3.5 \\
\hline 22 & 25 & $S$ & 74 & 1.71 & 1.85 & 12.0 & 12.0 \\
\hline 25 & 27 & S & 90 & 2.34 & 2.7 & 12.2 & 7.5 \\
\hline 26 & 38 & $\mathrm{O}$ & 87 & 5.98 & 7.1 & 15.7 & 18.0 \\
\hline
\end{tabular}

The samples for chemical analyses were taken from the epilimnion $(0.2 \mathrm{~m}$ from the surface) and above-bottom waters ( $0.2 \mathrm{~m}$ from the bottom). The samples were collected in one-liter bottles, transported in a portable refrigerator and kept at $4{ }^{\circ} \mathrm{C}$ until the remaining chemical analyses were performed in the Department of Water and Soil Analysis, Faculty of Chemistry, Adam Mickiewicz University in Poznań.

All the lakes were characterized in terms of the same set of physicochemical parameters: $\mathrm{O}_{2}, \mathrm{pH}$, electrical conductivity, $\mathrm{Ca}^{2+}, \mathrm{Na}, \mathrm{K}, \mathrm{Mg}^{2+}, \mathrm{NH}_{4}-\mathrm{N}, \mathrm{NO}_{3}-\mathrm{N}, \mathrm{NO}_{2}-\mathrm{N}, \mathrm{TN}, \mathrm{Fe}_{\text {tot }}, \mathrm{TC}, \mathrm{TP}, \mathrm{TS}$, color, and Secchi depth. The $\mathrm{pH}$ and electrical conductivity (EC) were measured using the Elmetron CX-701 meter, whereas the visibility was measured using a Secchi disc. Temperature and oxygen concentration were measured in vertical profiles using the Elmetron CX-401 meter. Additionally, vertical profiles of temperature and oxygen concentration were studied in the deepest and most stratified (according to Pukacz [21]) lakes: 8, 11, 12, 22, 25,26) and compared with the ones found in 1986. The measurements and samplings were performed at the beginning of August, in the deepest point of each lake (the same as was done in 1986). To assess the mictic type in all these lakes, additional measurements of vertical profiles of temperature and oxygen concentration were performed in autumn 2016 and spring 2017.

Concentrations of TC and TN were determined in the filtered samples by high-temperature combustion (HTC) using a Shimadzu TOC-L Total Organic Carbon analyzer (Shimadzu, Kyoto, Japan). For TN determination, the analyzer was equipped with a TNM-L TN unit (Shimadzu, Kyoto, Japan).

The color was determined by the visual method against the platinum scale. The concentrations of $\mathrm{NO}_{2}-\mathrm{N}, \mathrm{NO}_{3}-\mathrm{N}$ and $\mathrm{NH}_{4}-\mathrm{N}$ ions were determined by the ion chromatography method with a conductivity detector (Shimadzu, Kyoto, Japan) using Thermo AS22 with AG22 columns.

In order to determine $\mathrm{Ca}^{2+}$ and $\mathrm{Mg}^{2+}$ ion concentrations, a Metrohm ion chromatograph, 881 Compact IC Pro model (Metrohm, Herisau, Switzerland) was applied, using a Metrosep C4 Guard as the guard column and Metrosep C4 150 as the separating column. The $\mathrm{Fe}^{3+}$ concentration was determined by the spectrophotometric method.

The inductively coupled plasma optical emission spectrometer (ICP-OES) ICPE-9820 (Shimadzu, Kyoto, Japan) with a mini-torch was used for the qualitative and quantitative detection of $\mathrm{Na}, \mathrm{K}, \mathrm{Fe}_{\text {tot }}$, TP, and TS. Prior to the analysis, the Sigma-Aldrich (St. Louis, MO, USA) periodic table mix 1 for ICP containing $10 \mathrm{mg} \mathrm{L}^{-1}: \mathrm{Na}, \mathrm{K}, \mathrm{Fe}_{\text {tot }}$, TP and TS in 10\% nitric acid (comprising HF traces) was used for the calibration of ICP-OES. In order to preserve the standard/sample conditions, the matrix match method was used. The SRP in the water was determined by the molybdate method with ascorbic acid as a reducer. Prior to the analyses, the water samples were filtered through a rinsed $0.45 \mu \mathrm{m}$ pore size filter (Macherey-Nagel, Düren, Germany).

The results were compared with literature data given by Jędrczak [22] and Jachimko [23]. The first paper concerns the data collected in 1986, and the second set of data comes from 1992. 
Statistical analyses were performed using STATISTICA 12 (StatSoft Inc., Tulsa, OK, USA) software. The normality of distributions of the analyzed variables and the homoscedasticity of the samples were tested with the Shapiro-Wilk and Levene tests, respectively. Since non-normal distribution or unequal variances were stated for most of the variables, nonparametrical statistics were used. The Principal Components Analysis (PCA) was performed to determine physicochemical variability among the studied lakes. Prior to this analysis, the data (except $\mathrm{pH}$ values) was subject to logarithmic transformation $(\log (1+\mathrm{x}))$ to minimize the discrepancies between the empirical distribution of the variables and their theoretical normal variation. Additionally, to reduce the number of variables, simple factor analysis was applied. To determine which of the parameters differed significantly over the years, a nonparametric ANOVA was applied via the Kruskal-Wallis H-test. With these tests, three independent groups (water parameters in 1986, 1992 and 2016) were tested. The $H$ values larger than $5.9915(\mathrm{df}=2)$, allowed for rejecting the null hypothesis that there is no year-to-year differentiation. $p<0.05$ was accepted as statistically sound.

\section{Results}

The results of physicochemical analyses showed that the investigated lakes are very diverse in terms of most parameters (Figure 2). This particularly refers to color, conductivity, and the concentrations of $\mathrm{Mg}, \mathrm{Ca}, \mathrm{S}, \mathrm{Fe}$ and the mineral forms of nitrogen. Interestingly, $\mathrm{pH}$ was not among the most diverse parameters. The water of seven lakes had the reaction close to neutral (from 6.7 in lake no. 25 to 7.5 in lake No. 8). In the other lakes, water reaction was acidic (from pH 2.8 in lakes No. 12 and 22 up to $\mathrm{pH} 4.0$ in lake No. 14). The lowest values of Secchi depth (below $2 \mathrm{~m}$ ) and relatively high values of nutrients were observed in the lakes with the highest reaction.

The values most different from the mean were found in lake No. 12. This particularly refers to very high water mineralization (EC $>1000 \mu \mathrm{S} \mathrm{cm}{ }^{-1}$ and $4100 \mu \mathrm{S} \mathrm{cm}^{-1}$ in the epilimnion and hypolimnion, respectively). Lakes No. 22 and 26 also stood out in this respect. The lowest mean values and the highest visibility occurred in the water of lake No. 29.

Apart from differences between the lakes regarding most parameters, vertical diversity was also found between the epi- and hypolimnion waters. The greatest differences were observed in lakes No. 12, 22 and 26. They are surely the result of the fact that those lakes had the greatest depth and a clear vertical stratification.

PCA was performed in order to determine the physicochemical variability among the studied lakes. The outcome of the analysis (Figure 3) showed that the first and the second component explain $65.23 \%$ of the general variance. The PCA output proved that $\mathrm{pH}, \mathrm{EC}, \mathrm{Ca}, \mathrm{Mg}$ and $\mathrm{Fe}_{\text {tot }}$. (correlated with the first axis, $\mathrm{r}>0.75$ ) and $\mathrm{Na}, \mathrm{K}, \mathrm{NO}_{3}-\mathrm{N}$ (correlated with the second axis, $\mathrm{r}>0.6$ ) were primarily responsible for the variance observed. These parameters were the most important parameters for the lake-to-lake differentiation (the distance between particular cases). The weaker correlations (lesser importance) were found for $\mathrm{K}_{\text {and }} \mathrm{NH}_{4}-\mathrm{N}$ (correlated with the first axis, $\mathrm{r}=0.54$ for both) and $\mathrm{NO}_{2}-\mathrm{N}$ (correlated with the second axis, $\mathrm{r}=0.56$ ). In addition to the lake-to lake differentiation, distinct clusters of cases (distinguished groups of lakes) indicate temporal variation with consideration of the second principal component. The greatest differences were found between the years 1986 and 1992.

Despite year-to-year differentiation in each group, a similar pattern of distribution of cases (lakes) within the distinguished groups (years of the study) was observed. The greatest diversity between the lakes occurred in 1992. The outstanding lakes were lakes No. 11, 12, 14, 22 and 26. Those lakes had the lowest $\mathrm{pH}$ values and the highest values of mineralization and $\mathrm{NO}_{2}-\mathrm{N}, \mathrm{NH}_{4}-\mathrm{N}$ and $\mathrm{Fe}_{\text {tot }}$. ion concentrations.

The highest $\mathrm{pH}$ values and relatively lowest values of conductivity occurred in lakes No. 8, 10, 18, 20 and 25. In those lakes, a clear decrease in $\mathrm{Na}, \mathrm{K}, \mathrm{NO}_{3}-\mathrm{N}, \mathrm{Ca}$ and $\mathrm{Mg}$ occurred between the years 1986 and 2016. This makes them different from the other lakes.

The detailed analysis of the mean values (Table 2) confirmed significant temporal variability among the studied lakes with consideration of most the parameters studied. Although PCA showed 
an increase in the values of some parameters for five lakes $(11,12,14,22,26)$, the mean values of all the analyzed parameters decreased between the years 1986 and 2016.

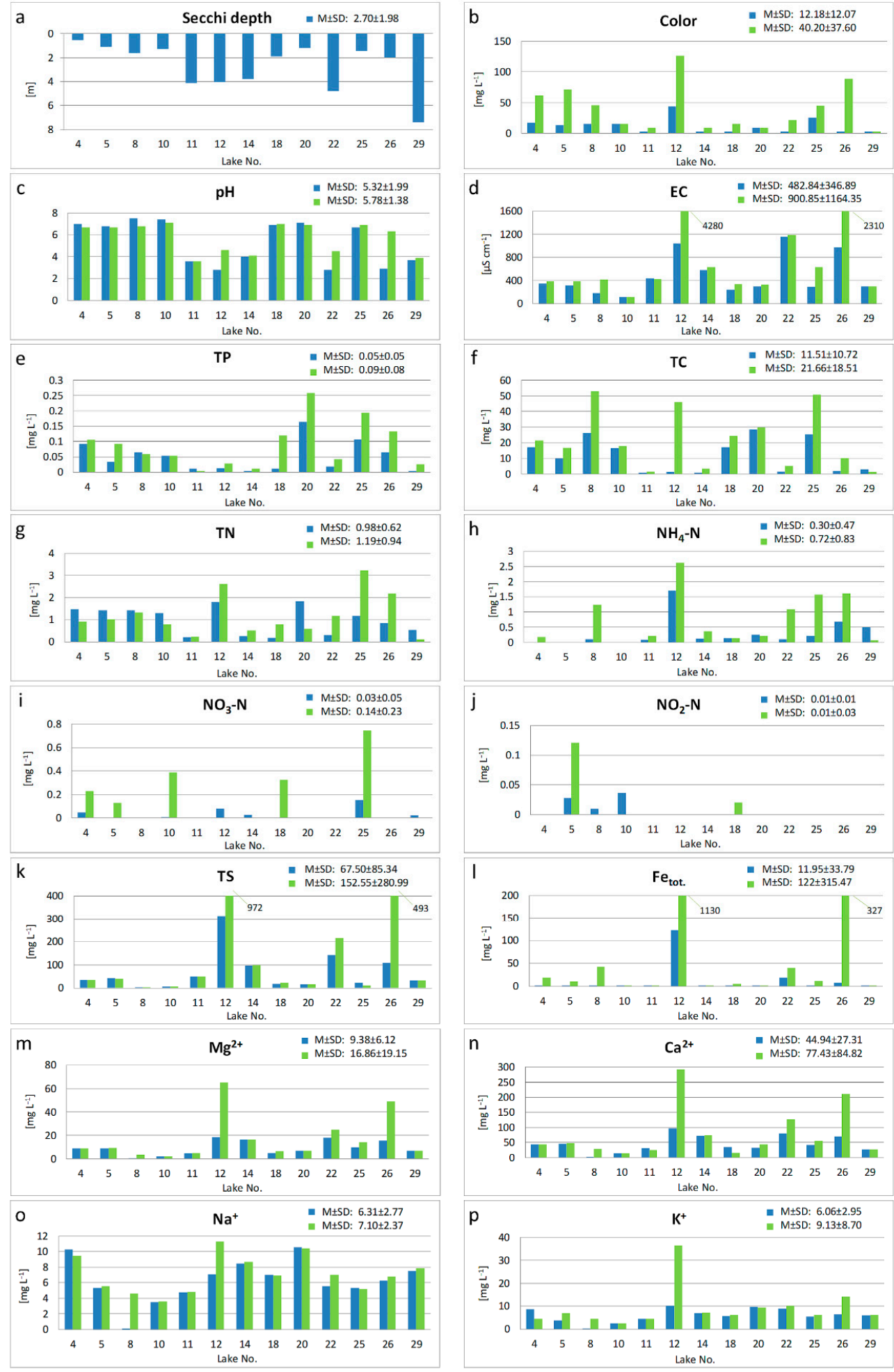

Figure 2. Physicochemical characteristic of the studied lakes: (a) -Scecchi depth, (b)—color, (c) - $\mathrm{pH},(\mathbf{d})$ - electrical conductivity, (e) - total phosphorus, (f) - total carbon, (g) - total nitrogen, (h)—ammonium nitrogen, (i) — nitrate nitrogen, (j) —nitrite nitrogen, (k) —total sulphur, (1) — total iron, (m)—magnesium, (n)—calcium, (o)—sodium, (p)—potassium. Blue column—epilimnion water, green column-hypolimnion water. $\mathrm{M} \pm \mathrm{SD}$ indicates the mean and standard deviation. 


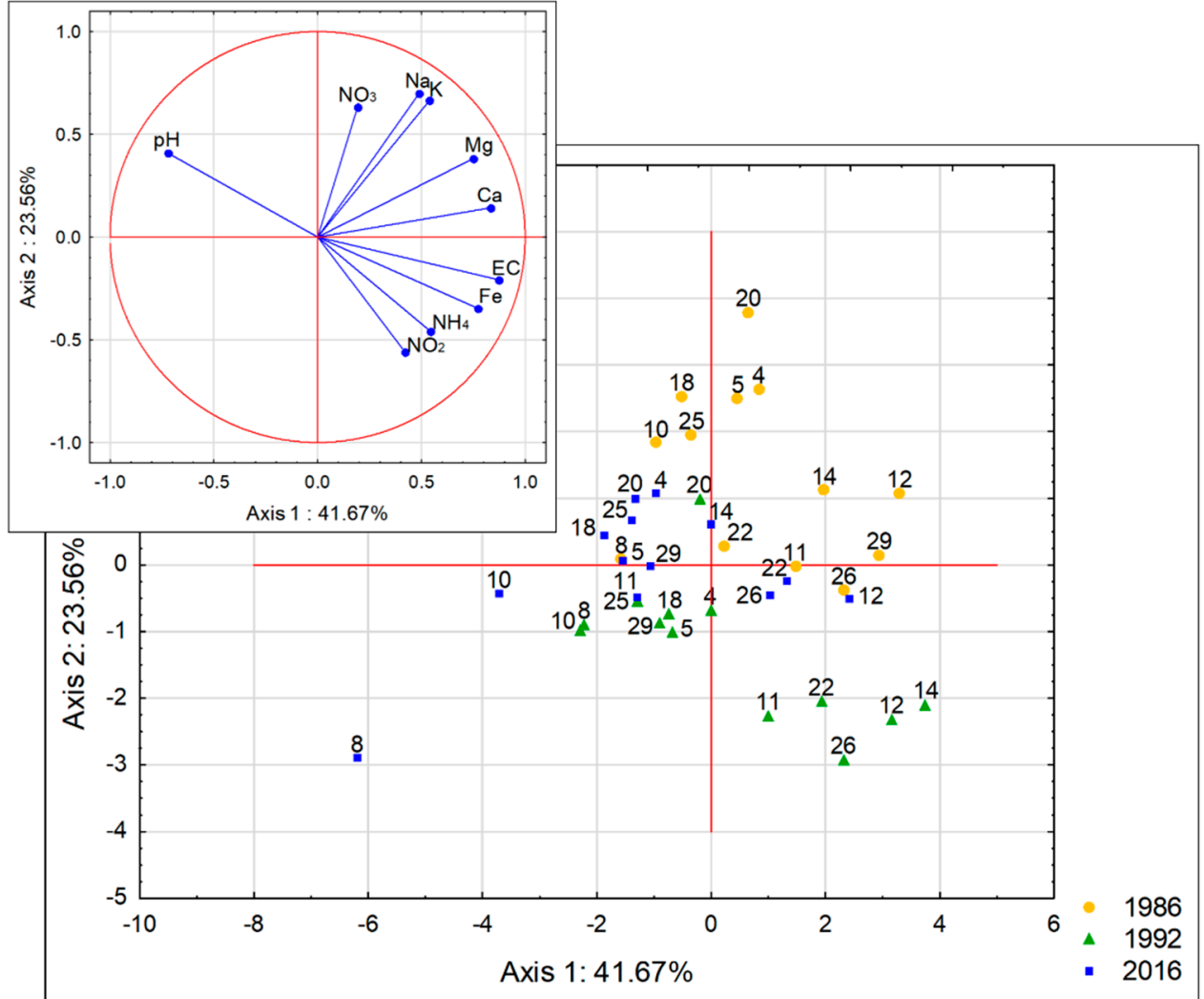

Figure 3. Principal Components Analysis (PCA) for the lakes studied in the Muskau Arch-differentiation across the selected hydrochemical characteristics (preceded by factor analysis). The distinguished groups (colored) indicate the years of study. Explanations: $\mathrm{NO}_{3}$ —nitrate nitrogen, $\mathrm{NH}_{4}-\mathrm{N}$-ammonium nitrogen, $\mathrm{NO}_{2}-\mathrm{N}$-nitrite nitrogen, $\mathrm{Ca}$-calcium, $\mathrm{Na}$-sodium, $\mathrm{K}$ - potassium, $\mathrm{Mg}$-magnesium, Fe-total iron, EC—electrical conductivity.

Table 2. Physicochemical characteristics (Mean \pm SD) of the analyzed lakes and the Kruskal-Wallis test across the years of study * by Jędrczak [24] and ${ }^{* *}$ by Jachimko [29].

\begin{tabular}{|c|c|c|c|c|c|c|}
\hline \multirow{2}{*}{ Variable } & \multirow{2}{*}{ Unit } & \multirow{2}{*}{$\begin{array}{c}1986 * \\
(n=13)\end{array}$} & \multirow{2}{*}{$\begin{array}{l}1992 * * \\
(n=13)\end{array}$} & \multirow{2}{*}{$\begin{array}{c}2016 \\
(n=13)\end{array}$} & \multicolumn{2}{|c|}{ Kruskal-Wallis Test } \\
\hline & & & & & $H$ & $p$ \\
\hline $\mathrm{pH}$ & & $5.369 \pm 2.250$ & $5.105 \pm 2.299$ & $5.323 \pm 1.990$ & 0.0320 & 0.9692 \\
\hline EC & $\left(\mu \mathrm{S} \mathrm{cm}{ }^{-1}\right)$ & $677.692 \pm 370.634$ & $866.539 \pm 710.654$ & $482.846 \pm 346.891$ & 3.8363 & 0.1469 \\
\hline $\mathrm{O}_{2}$ & $\left(\mathrm{mg} \mathrm{L}^{-1}\right)$ & $7.861 \pm 1.138$ & $6.954 \pm 0.984$ & $6.262 \pm 1.312$ & 10.4230 & 0.0054 \\
\hline $\mathrm{Na}$ & $\left(\mathrm{mg} \mathrm{L}^{-1}\right)$ & $16.008 \pm 13.099$ & $5.600 \pm 2.842$ & $6.310 \pm 2.773$ & 4.9656 & 0.0835 \\
\hline K & $\left(\mathrm{mg} \mathrm{L}^{-1}\right)$ & $10.285 \pm 8.722$ & $4.315 \pm 2.361$ & $6.062 \pm 2.948$ & 6.7587 & 0.0341 \\
\hline $\mathrm{Ca}$ & $\left(\mathrm{mg} \mathrm{L}^{-1}\right)$ & $62.462 \pm 46.960$ & $56.915 \pm 32.544$ & $44.939 \pm 27.311$ & 1.1232 & 0.5703 \\
\hline $\mathrm{Mg}$ & $\left(\mathrm{mg} \mathrm{L}^{-1}\right)$ & $39.385 \pm 18.888$ & $13.900 \pm 8.529$ & $9.382 \pm 6.116$ & 21.7183 & 0.0000 \\
\hline $\mathrm{Fe}$ & $\left(\mathrm{mg} \mathrm{L}^{-1}\right)$ & $20.786 \pm 49.168$ & $21.737 \pm 53.930$ & $11.951 \pm 33.786$ & 1.1356 & 0.5668 \\
\hline $\mathrm{NH}_{4}-\mathrm{N}$ & $\left(\mathrm{mg} \mathrm{L}^{-1}\right)$ & $1.364 \pm 1.708$ & $2.339 \pm 1.553$ & $0.301 \pm 0.468$ & 19.3414 & 0.0000 \\
\hline $\mathrm{NO}_{2}-\mathrm{N}$ & $\left(\mathrm{mg} \mathrm{L}^{-1}\right)$ & $0.012 \pm 0.010$ & $1.211 \pm 2.036$ & $0.006 \pm 0.012$ & 28.5339 & 0.0000 \\
\hline $\mathrm{NO}_{3}-\mathrm{N}$ & $\left(\mathrm{mg} \mathrm{L}^{-1}\right)$ & $0.379 \pm 0.222$ & $0.006 \pm 0.009$ & $0.025 \pm 0.045$ & 28.5339 & 0.0000 \\
\hline
\end{tabular}

The results of the Kruskal-Wallis $\mathrm{H}$ test $(H(2)>5.9915)$ showed statistically significant differences $(p<0.05)$, for six of the studied variables: $\mathrm{O}_{2}, \mathrm{Na}, \mathrm{K}, \mathrm{Mg}, \mathrm{NO}_{3}-\mathrm{N}$ and $\mathrm{NO}_{2}-\mathrm{N}$. The greatest differences $(p<0.000)$ were found for $\mathrm{K}, \mathrm{NO}_{3}-\mathrm{N}$ and $\mathrm{NO}_{2}-\mathrm{N}$. These parameters were also among the most important for the year-to-year lake differentiation in the PCA output. Interestingly, no significant variation was found for parameters most strongly correlated with the first principal component, i.e., $\mathrm{pH}, \mathrm{EC}, \mathrm{Ca}$ and $\mathrm{Fe}_{\text {tot }}$. 
The analysis of thermal-oxygen profiles of 6 selected lakes (Figure 4 ) showed considerable changes in their stratification between 1986 and 2016. In all these lakes, except for lake No. 12, the stratification range has increased (as a result of depth changes). Although there is a distinct differentiation in values between 1986 and 2016, their pattern seems to be similar to a large extent, indicating the similarity in character of the stratification. In 2016, higher temperatures were observed, particularly in the surface layer. The same was true for oxygen concentration, which was lower in the year 2016 (except in lakes No. 25 and 26). In five lakes, hypoxic to anoxic conditions, i.e., gradual decrease of oxygen concentration with the depth, occurred in the deepest layers of water. The only exception was lake No. 11, where oxygen concentration increased along with depth, both in 1986 and in 2016. In spite of differences in depth, a similar pattern of oxygen and thermal profiles was found in most lakes. This is particularly true for lake No. 12. In this lake, as well as in lakes No. 8, 25 and 26, conditions typical of meromixis were found, which was confirmed by additional measurements performed in the fall of 2016 and spring of 2017. This is also evident from the higher hypolimnetic values for EC and metal concentrations in these lakes (Figure 2). The other two lakes were dimictic.
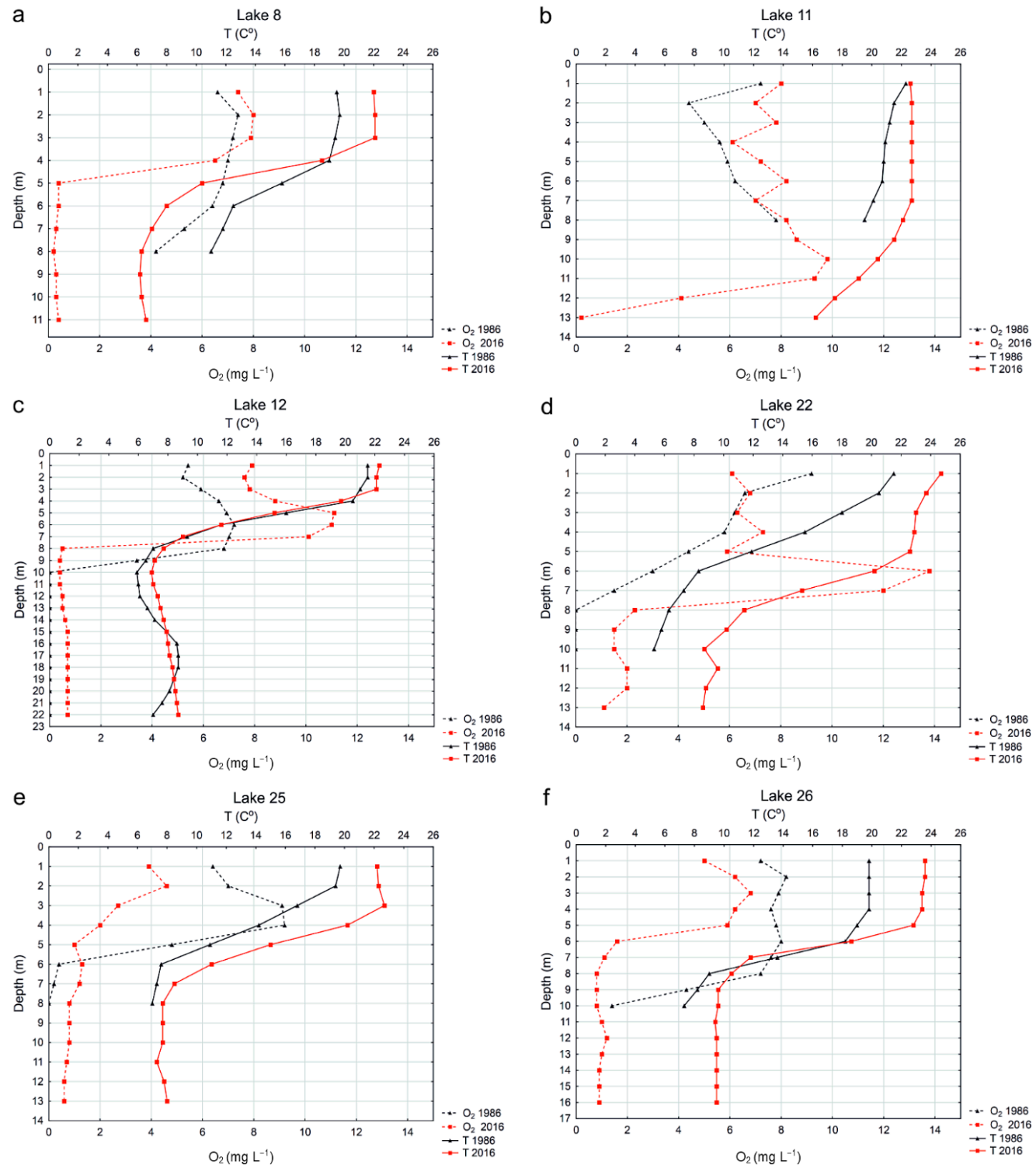

Figure 4. The comparison of thermal and oxygen vertical profiles performed for selected lakes during summer stagnation in 1986 and 2016. Explanations: (a)—Lake No. 8, (b)—Lake No. 11, (c)—Lake No. 12, (d)-Lake No. 22, (e)—Lake No. 25, (f)-Lake No. 26. 


\section{Discussion}

The performed analyses showed that the pit lakes of the Muskau Arch are very diverse in terms of habitat conditions, which was reflected both in their water chemistry and in bathymetry. This is largely the effect of their genesis [30] and of changes connected with hydrochemical processes [1] and secondary succession [31]. Although water chemistry in those lakes differs much from that in natural lake ecosystems, we can clearly see that they are subject to similar processes connected i.e., with depth (clear vertical stratification) or age (the youngest lakes have the lowest $\mathrm{pH}$ and the highest water mineralization).

Comparative analysis reveals considerable changeability within the last 30 years. This results both from the research carried out in the 1980s and 1990s [24] and from contemporary research outcomes [23,27]. However, the similar distribution of temporal variability observed for the majority of lakes may suggest that the changes occurring in them for years are rather even, regardless of lake-to-lake differentiation. In our opinion, this is mostly the effect of the close proximity of the lakes, which means that they are within the same aquifers and are fed by rainwater in a similar way. This is also reflected in our findings. This hypothesis seems to be supported by the fact that in July and August 1986, very high values of precipitation were observed (IMGW-BIP climatic data), which may have contributed to the intensification of washing out and oxidation of pyrite $\left(\mathrm{FeS}_{2}\right)$. This mineral is stable as long as it is under anoxic conditions. Washing out the overburden and the surface layers of lignite causes the aeration of pyrite and thus its microbial oxidation after mining [32]. Moreover, the ferric iron and oxidized manganese species precipitate with increasing $\mathrm{pH}$. At the same time, concentrations of iron and manganese can still be elevated under neutral conditions due to the high solubility of iron (II) and manganese (II) at anoxic conditions. Hence, this process is important not only for geochemical changes, but by differentiating density, it also significantly influences water stratification [17].

It may be concluded, then, that the $\mathrm{pH}$ variety of Muskau Arch lakes is, on the one hand, the consequence of pyrite content in the surrounding subsoil (mainly the overburden), and on the other hand, of the degree of its oxidation and washing out, which could have been the cause of lower values in 1986. It is worth mentioning that $\mathrm{pH}$ probably also had a significant impact on the diversity of the other physicochemical parameters.

The importance of washing out the subsoil is also visible in the case of concentrations of $\mathrm{Na}, \mathrm{K}$ and $\mathrm{NH}_{4}$ ions in lakes No. 4, 5, 12,14, 18 and 20 in 1986. The main source of these ions is the washing out of potassium salts [13], present in the deposits of brown coal in that area. At the places of water outflow they are visible in the form of characteristic sediment [30]. High values of lower oxidation number forms of nitrogen in lakes No. 12, 14, 22 and 26 can also be explained with the fact that these are among the youngest lakes in that region and are mostly fed with groundwaters [3]. It is worth mentioning that the very low $\mathrm{pH}$ and high concentrations of nitrite nitrogen and ammoniacal nitrogen (up to $0.85 \mathrm{mg} \mathrm{L}^{-1} \mathrm{~N}-\mathrm{NO}_{2}$ and $0.86 \mathrm{mg} \mathrm{L}^{-1} \mathrm{~N}-\mathrm{NH}_{4}$ in lakes 14 and 26 , respectively) were also found in those lakes in 2016. This has a negative impact on the conditions of development of living organisms, i.e., amphibians and fish, for which these values are toxic [2].

An important element concerning the diversity and evolution of pit lakes is human-imposed water neutralization [9]. In the 1980s and 1990s, some lakes were limed and fertilized with wastewater in order to neutralize the water and ensure better conditions for fish breeding. This was done at lakes No. 8, 10, 18, 20 and 25 (oral source of information-unpublished data), where the $\mathrm{pH}$ values are the highest and relatively most stable. Liming was probably performed in those lakes using calcium hydroxide, causing the precipitation of i.e., $\mathrm{Ca}$ and $\mathrm{Mg}$ salts [9], which explains the clear decrease in the values between 1986 and 2016. The fact that there were no significant differences in the concentration of calcium, sodium, and potassium may be explained by low dependence on $\mathrm{pH}$. According to [17] this may be due to the formation of secondary minerals, such as gypsum and jarosite. It seems particularly evident in lakes No. 8 and 10, where wastewater discharge (as well as washing water carts carrying liquid manure) was frequent [21]. Currently, these lakes are used for fishing purposes. 
The use of wastewater in order to improve the lakes' fertility seems to be confirmed by evidently higher values of $\mathrm{NH}_{4}-\mathrm{N}$ concentration in 1992. In addition, the findings of studies from years 2016 and 2017 [21] show that, in these lakes, there were the highest values of Chla and TN, the highest fraction of which was organic nitrogen.

In our opinion, changes in the morphometric structure also contributed significantly to the diversity of water chemistry. Our measurements, compared with the data by Jedrczak [24], showed a considerable increase in the depth (even up to $6 \mathrm{~m}$ ) of most the lakes. Based on observations of trees, fishing platforms and shoreline, we have also concluded there were no significant changes in water level over the last 30 years. Still, it was found that all the lakes have reduced in their surface area. This is the effect of underground workings caving in and the compaction of the loose subsoil [13]. It occurs in lakes formed in sink holes after closure of underground mining pits [3]. As a result, in such places the water table may seemingly be lower. The speed of subsoil settlements is hard to determine and there is no literature data in this regard. However, on the basis of the data we have collected, for the studied lakes, it may be estimated at between 0.1 and $0.2 \mathrm{~m}$ per annum. The fact that only the surface area of the lakes has decreased is probably due to the processes of shoreline erosion and slow overgrowing with vegetation. The only lake where the depth did not change over the years was lake No. 12 . It is the youngest of all the studied lakes and the only one to have been formed in the place of an open pit [3]. Most likely, the slopes of the lake continue to slide down there, causing gradual shallowing.

The findings of our study suggest the need to update the previous data concerning the morphometry of Muskau Arch lakes. This is pointed out by the example of lake No. 26, which used to be classified as an open pit lake [27]. This lake is an example of one of the greatest increases in depth within the latest 30 years, which suggests that an underground mine may have been there originally.

Changes in the depth of lakes have a significant impact on the occurring hydrochemical processes, including the ratio of the epilimniom and hypolimnion [4]. However, mixing depth is also determined by heat exchange, wind stress, and light absorption [11]. Thus, shading by trees or topographic effects might have an influence. Most of those lakes are in forested areas and thus wind and solar shading play their roles. Unfortunately, for the studied lakes there is no data available that could be used to carry out a reliable comparative analysis of deep layer waters. Still, the obtained thermal and oxygen profiles show similar stratification patterns in most of the lakes as compared to 1986. Further investigation of possible mixing scenarios using modeling would be needed to infer possible transitions over these 30 years. The advancing deepening only seems to consolidate specific mictic types (unless altered by humans). This particularly refers to the deepest lakes, where increased depth promotes the development of meromictic conditions [17,33]. Four of the studied lakes have been classified as meromictic, though only two of them (No. 12 and 26) were considered as meromictic before $[4,29]$. Although the increase in depth generally fosters the stabilization of physicochemical properties of a lake [11], our study showed that the deepest lakes displayed the greatest temporal variability of the analyzed parameters. This may be due to the periodic feeding of acidified mine waters, which causes significant fluctuations in sulphate (VI) concentration and enrichment of the bottom water layers with iron (II) compounds [13]. This process also leads to increased mineralization in deeper water layers, stabilizing vertical stratification. It was indicated by a comparison of epilimnion and hypolimnion chemistry, showing a very high mineralization in the bottom waters.

An important factor affecting water chemistry of the studied lakes is the changing climatic conditions, which affect the inflow of water and the biogeochemical changes, e.g., the redox potential and microbiota activity [17]. The analysis of temperature in the lakes showed that in 2016, temperature in all lakes was higher at the surface than in 1986. Although our measurements do not cover intermediate years and were made in particular months this difference may result from the climatic changes occurring over the years that have been confirmed for natural lakes in many regions of the world [34]. According to the data from the Institute of Meteorology and Water Management, in 1986 the mean annual temperature in the Lubuskie region was $11.7^{\circ} \mathrm{C}$, and in $2016,13.7^{\circ} \mathrm{C}$. This affected, not only the thickness of epilimnion, but also the speed of chemical processes occurring in water, e.g., 
the impact of temperature increase on the nitrogen oxidation number [35]. Data analysis shows that the content of nitrite nitrogen and ammoniacal nitrogen in water was much higher in 1986 than in 2016. One example is lake No. 14, where in $1986, \mathrm{NO}_{2}-\mathrm{N}$ concentration was $0.005 \mathrm{mg} \mathrm{L}^{-1}$ and $\mathrm{NO}_{3}-\mathrm{N}$ concentration was $0.5 \mathrm{mg} \mathrm{L}^{-1}$, while in 2016, the concentrations were $0.001 \mathrm{mg} \mathrm{L}^{-1}$ and $0.027 \mathrm{mg} \mathrm{L}^{-1}$, respectively. In recent years (2018 and 2019), record high temperatures and a lowering of the water table in all lakes were observed. In our opinion, this may significantly accelerate the physicochemical processes occurring there and lead to irreversible changes.

The overall analysis of the obtained results seems to confirm our hypothesis that the lakes undergo temporal variability of physical-chemical water conditions resulting not only from the natural evolution (e.g., hydrochemical processes, secondary succession) but also from dynamic hydrology induced by human activity (neutralization). Unexpectedly, our analyses also showed an increase in the depth of most lakes, which may also affect the dynamics of their transformation. As a result, it may also be important for landscape diversification in the future. Similar processes are probably taking place in other postmining regions, but there is no literature data concerning this issue. Taking into consideration the unique character of these lakes and their environment and landscape formation role, it is necessary to learn the exact processes occurring therein and to protect them.

\section{Conclusions}

The performed analyses showed that the pit lakes of the Muskau Arch are very diverse in terms of the physicochemical water conditions. This particularly refers to mineralization, including the concentration of the analyzed metal ions.

Distinct temporal variability of the analyzed physicochemical parameters within the last 30 years has been found. An important and unexpected factor for temporal and spatial variability alike is the secondary deepening of the lakes as a result of the bottom subsiding, which we found in our research. This phenomenon requires detailed research, since there is no literature data to with which to compare. In addition, temporal variability of water chemistry does not only result from natural processes, but also from human activity (neutralization and water fertilization). An important process that may contribute to further variability is the increasing temperature and the related lowering of the water table.

The presented results and numerous data gaps over the years indicate the need to extend the research on the Muskau Arch lakes. A consistent monitoring plan seems necessary to understand the complex processes taking place and effectively protect these valuable objects.

Author Contributions: Conceptualization, A.P.; Methodology and investigation, A.P., M.O.-G., M.F.; Data analysis, A.P., M.O.-G., M.F.; Writing-original draft preparation, A.P., M.O.-G., L.J.; Writing—review and editing, A.P, M.O.-G., L.J. All authors have read and agreed to the published version of the manuscript.

Funding: The APC was founded by Adam Mickiewicz University and University of Zielona Góra. The research received no external funding.

Acknowledgments: We wish to thank Brigitte Nixdorf (Cottbus) for the constructive criticism of the MS as well as comments of two anonymous reviewers and journal editor help to improve the manuscript.

Conflicts of Interest: The authors declare no conflict of interest.

\section{References}

1. Sienkiewicz, E.; Gasiorowiski, M. The evolution of a mining lake-From acidity to natural neutralization. Sci. Total Environ. 2016, 557-558, 343-353. [CrossRef] [PubMed]

2. Blanchette, M.L.; Lund, M.A. Pit lakes are a global legacy of mining: An integrated approach to achieving sustainable ecosystems and value for communities. Curr. Opin. Environ. Sustain. 2016, 23, 28-34. [CrossRef]

3. Koźma, J. Anthropogenic landscape changes connected with the old brown coalmining based on the example of the Polish part of the Muskau Arch area. Górn. Odkryw. 2016, 3, 1-13. 
4. Schultze, M.; Boehrer, B. Development of Two Meromictic Pit Lakes-A Case Study from the Former brown coal Mine Merseburg-Ost, Germany. In Proceedings of the 10th IMWA Congress: Mine Water and the Environment, Karlovy Vary, Czech Republic, 2-5 June 2008; pp. 611-614.

5. Kasztelewicz, Z. Pros and cons of coal mining in Poland. Polityka Energ. 2012, 15, 7-27.

6. Koschorreck, M.; Tittel, J. Benthic photosynthesis in an acidic mining lake (pH 2.6). Limnol. Oceanogr. 2002, 47, 1197-1201. [CrossRef]

7. Moser, M.; Weisse, T. The most acidified Austrian lake in comparison to a neutralized mining lake. Limnologica 2011, 41, 303-315. [CrossRef]

8. Brugam, R.B.; Gastineau, J.; Ratcliff, E. The neutralization of acidic coal mine lakes by addition of natural organic matter: A mesocosm test. Hydrobiologia 1995, 316, 153-159. [CrossRef]

9. Nixdorf, B.; Uhlmann, W.; Lessmann, D. Potential for remediation of acidic mining lakes evaluated by hydrogeochemical modelling: Case study GrunewalderLauch (Plessa 117, Lusatia/Germany). Limnologica 2010, 40, 167-174. [CrossRef]

10. Schultze, M. Limnology of Pit Lakes. In Acidic Pit Lakes, The Legacy of Coal and Metal Surface Mines; Geller, W., Schultze, M., Kleinmann, B., Wolkersdorfer, C., Eds.; Springer: Berlin/Heidelberg, Germany, 2013; pp. $23-224$.

11. Wetzel, R.G. Limnology, Lake and River Ecosystems, 3rd ed.; San Diego Academic Press: San Diego, CA, USA, 2001.

12. Boehrer, B.; Rohden, C.; Schultze, M. Physical Features of Meromictic Lakes: Stratification and Circulation. Ecol. Meromictic Lakes 2017. [CrossRef]

13. Friese, K.; Herzsprung, P.; Schultze, M. Limnochemistry of Water and Sediments of Acidic Pit Lakes. In Acidic Pit Lakes, the Legacy of Coal and Metal Surface Mines; Geller, W., Schultze, M., Kleinmann, R., Wolkersdorfer, C., Eds.; Springer: Berlin/Heidelberg, Germany, 2013; pp. 42-75.

14. Joehnk, K.; Uhlmann, W. Persistence of meromictic stratification in post mining lakes. Min. Meets Water Confl. Solut. 2016, 199-200.

15. Pieters, R.; Lawrence, G.A. Physical processes and meromixis in pit-lakes. Can. J. Civil Eng. 2014, 41, 569-578. [CrossRef]

16. Gammons, C.; Harris, L.N.; Castro, J.M.; Cott, P.; Hanna, B. Creating lakes from open pit mines: Processes and considerations, with emphasis on northern environments. Can. Tech. Rep. Fish. Aquat. Sci. 2009, 1-106.

17. Geller, W.; Klapper, H.; Schultze, M. Natural and Anthropogenic Sulphuric Acidification of lakes. In Acidic Pit Lakes, Acid Main Drainage, Limnology and Reclamation; Geller, W., Schultze, M., Kleinmann, B., Wolkersdorfer, C., Eds.; Springer: Berlin/Heidelberg, Germany, 2013; pp. 3-15.

18. Wendt-Potthoff, K.; Frommichen, R.; Herzsprung, P.; Koschorreck, M. Microbial Fe(III) reduction in acidic mining lake sediments after addition of an organic substrate and lime. Water Air Soil Pollut. 2002, 2, 81-96. [CrossRef]

19. Matejczuk, W. Plankton poeksploatacyjnych zbiorników wodnych z rejonu Trzebiela (Plankton of pit lakes in the miningexcavations in Trzebiel area), [w:] Radkiewicz, J. (red.). Przyr. Środk. Nadod 1989, 1, 93-118. (In Polish, English summary).

20. Kasiński, J.R.; Koźma, J.; Gawlikowska, E. Geotopes of the proposed Muskau arch geopark-Inventory classification and evaluation. Proceedings, Conference on Geological Heritage Concept, Conservation and Protection Policy in Central Europe. PGI Spec. Pap. 2004, 13, 73-88.

21. Jachimko, B.; Kasprzak, M. Zmiany składu chemicznego wód kopalnianego zbiornika zapadliskowego (Chemical composition of water in post-mining reservoir of impact origin). Rocz. Ochr. Środ. 2011, 13, 1751-1765.

22. Jedrczak, A.; Jachimko, B.; Najbar, B. Zmiany fizyczno-chemicznych cech wód największego zbiornika meromiktycznego na pojezierzu antropogenicznym w okresie kilkunastu lat (Changes in physical—chemical characteristics of the largest water meromictic reservoir of anthropogenic pit lakes in the Muskau Arch during several years) Zeszyty Naukowe Politechniki Zielonogórskiej-Inżynieria Środowiska. Zielona Góra 1998, 116, 5-17.

23. Lutyńska, S.; Labus, K. Identification of processes controlling chemical composition of pit lakes waters located in the eastern part of Muskau Arch (Polish-German borderland). Arch. Environ. Prot. 2015, 41, 60-69. [CrossRef] 
24. Jędrczak, A. Skład chemiczny wód pojezierza antropogenicznego w Łuku Mużakowskim (Chemical composition of anthropogenic pit lakes in the Muskau Arch). Wydawnictwo WSI ZielonaGóra 1992, 1-139. (In Polish, English Summary).

25. Lund, M.A.; Mccullough, C.D. Biological remediation of low sulphate acidic pit lake waters with limestone $\mathrm{PH}$ neutralisation and nutrients. In Proceedings of the International Mine Water Conference, Pretoria, South Africa, 19-23 October 2009; pp. 519-525.

26. Allard, B.; Bäckström, M.; Karlsson, S.; Grawunder, A. Neutralisation of an acidic pit lake by alkaline waste products. Environ. Sci. Pollut. Res. 2014, 21, 6930-6938. [CrossRef]

27. Pukacz, A.; Oszkinis-Golon, M.; Frankowski, M. The physico-chemical diversity of pit lakes of the Muskau Arch (Western Poland) in the context of their evolution and genesis. Limnol. Rev. 2018, 18, 115-126. [CrossRef]

28. Dawczyk, G.; Maciantowicz, M. Dawne górnictwo I kolejnictwo na terenie Łuku Mużakowa, Aus der Geschichte des Bergbaus Und der Bahnim Muskauer Faltenbogen (Former mining and railway in the area of the Muskau Arch). Druk. Chroma 2014, 180. (In Polish, English Summary).

29. Jachimko, B. Krążenie fosforu w wodach zbiorników Pojezierza Mużakowskiego (Circulation of Phosphorus in Waters of Muskau Arch). Ph.D. Thesis, Pol. Wrocł., Instyt. Inż. Ochr. Środ., Wrocław, Poland, 1998.

30. Koźma, J.; Kupetz, M. The transboundary Geopark MuskauArch. Prz. Geol. 2008, 56, 692-698.

31. Kupetz, M. Geologischer bau und genese der Stauchendmoräne Muskauer Faltenbogen. Brandenbg. Geowiss. Beitr. 1997, 4, 1-20.

32. Schultze, M.; Pokrandt, K.-H.; Hille, W. Pit lakes of the Central German brown coal mining district: Creation, morphometry and water quality aspects. Limnol. Ecol. Manag. Inland Waters 2010, 40, 148-155. [CrossRef]

33. Dunbar, D. Modelling of pit lakes. In Acidic Pit Lakes, the Legacy of Coal and Metal Surface Mines; Geller, W., Schultze, M., Kleinmann, B., Wolkersdorfer, C., Eds.; Springer: Berlin/Heidelberg, Germany, 2013; pp. 186-224.

34. Woolway, R.I.; Merchant, C.J. Worldwide alteration of lake mixing regimes in response to climate change. Nature Geosci. 2019, 12, 271-276. [CrossRef]

35. Zheng, L.; Cardenas, M.B.; Wang, L. Temperature effects on nitrogen cycling and nitrate removal-production efficiency in bed form-induced hyporheic zones. J. Geophys. Res. 2016, 121, 1086-1103. [CrossRef]

(C) 2020 by the authors. Licensee MDPI, Basel, Switzerland. This article is an open access article distributed under the terms and conditions of the Creative Commons Attribution (CC BY) license (http://creativecommons.org/licenses/by/4.0/). 